\section{Adaptation and validation of the Indonesian version of the FRAIL scale and the SARC-F in older adults}

\author{
Lazuardhi Dwipa ${ }^{1}$, MD; Muhamad Apandi ${ }^{1}$, MD; Priyo Panji Utomo ${ }^{1}$, MD; Mira \\ Hasmirani $^{1}$ MD; Alif Bagus Rakhimullah ${ }^{1,2}$, MD; Fajar Awalia Yulianto ${ }^{3}$, MD; \\ Yuni Susanti Pratiwi ${ }^{4}, \mathrm{MD}, \mathrm{PhD}$
}

\begin{abstract}
Objective. To adapt and validate the Indonesian version of the FRAIL scale (Ina-FRAIL) and the SARC-F (Ina-SARC-F).
\end{abstract}

Methods. The Ina-FRAIL and the Ina-SARC-F were developed through forwards-backwards translation, and their validity (itemtotal item correlations), internal consistency (Cronbach's alpha), and test-retest reliability (kappa statistic) were determined. The diagnostic performance of the Ina-FRAIL and the Ina-SARC-F was evaluated using the receiver operating characteristic curve analysis.

Results. A total of 101 (57 men and 44 women) and 64 (23 men and 41 women) patients were included in the validation of the Ina-FRAIL scale and the Ina-SARC-F, respectively. For the Ina-FRAIL scale, internal consistency coefficient was 0.530 , and test-retest reliability was 0.951 $(\mathrm{p}<0.001)$.The correlation coefficients between the total score and items of fatigue, resistance, ambulation, illness, and loss of weight were 0.503 , $0.813,0.679,0.561$, and 0.317 , respectively (all $\mathrm{p}<0.001$ ). Correlation between the Ina-FRAIL scale and the Cardiovascular Health Study was strong ( $\mathrm{rs}=0.696, \mathrm{p}<0.001$ ). Using the cut-off value of $\geq 2$, the diagnostic performance of the Ina-FRAIL was $80 \%$ sensitivity and $70.4 \%$ specificity. For the Ina-SARC-F, internal consistency was 0.851 , and test-retest reliability was $1.00(\mathrm{p}<0.001)$. The correlation coefficients between the total score and items of strength, ambulation, rising, climbing, and falls were $0.646,0.775,0.653,0.685$, and 0.580 , respectively (all $r>0.361$ and $\mathrm{p}<0.001$ ). Using the cut-off value of $\geq 3$, the diagnosis performance of the Ina-SARC-F was $100 \%$ sensitivity and $61.7 \%$ specificity.

Conclusions. The Ina-FRAIL scale and the Ina-SARC-F are valid and reliable tools to screen for frailty syndrome and sarcopenia, respectively.

Key words: Frailty; Mass screening; Sarcopenia

\section{ORIGINAL ARTICLE}

\author{
Department of Internal Medicine, Faculty \\ of Medicine Universitas Padjadjaran / \\ Hasan Sadikin Hospital, Bandung, \\ Indonesia \\ 2 Universitas Islam Bandung, Bandung, \\ Indonesia \\ Department of Public Health, Medical \\ Faculty, Universitas Islam Bandung, \\ Bandung, Indonesia \\ 4 Department of Biomedical Science, \\ Faculty of Medicine, Universitas \\ Padjadjaran, Bandung, Indonesia
}

Correspondence to: Lazuardhi Dwipa, Geriatric Division, Department of Internal Medicine, Faculty of Medicine, Universitas Padjadjaran, Hasan Sadikin Hospital, Bandung 40161, Indonesia. Email: lazuardhi.d@gmail.com

\section{INTRODUCTION}

In Indonesia, the number of people aged $\geq 60$ years was 18.1 million in 2010 (accounting for $7.6 \%$ of the total population) and is projected to increase to 33.7 million by 2025 and 48.2 million by $2035 .{ }^{1}$ In older adults, frailty syndrome and sarcopenia resulting from age-associated declines in physiologic reserve and function across multiple organ systems increase vulnerability to adverse outcomes such as fall, infection, hospitalisation, disability, and increased mortality. ${ }^{2}$ Frailty is a clinical syndrome defined as having $\geq 3$ of five frailty phenotypes: weakness, slowness, low physical activity, selfreported exhaustion, and unintentional weight loss. ${ }^{3}$ There are validated instruments to detect frailty 
syndrome and sarcopenia, but these instruments need sophisticated modalities and trained assessor and require a long time to assess. ${ }^{4}$ This is challenging in the clinical setting of Indonesia with a heavy workload, especially in primary healthcare. Hence, the FRAIL scale (for frailty) and the SARC-F (for sarcopenia) were developed; each comprises only five questions for more convenient and less timeconsuming assessment. ${ }^{5-8}$ This study aimed to adapt and validate the Indonesian version of the FRAIL scale (Ina-FRAIL) and the SARC-F (Ina-SARC-F).

\section{METHODS}

This cross-sectional study was approved by the ethics committee of Hasan Sadikin General Hospital (reference: LB.04.01/A05/EC/269/VIII/2016 and LB.04.01/A05/EC/436/X/2015). Patients aged $>60$ years who could communicate in Indonesian language and answer questions for themselves were included.
Patients with cognitive impairment or unable to stand or walk were excluded. For Ina-SARC-F validation, patients with dehydration or limb oedema were also excluded.

The Indonesian versions of the FRAIL scale and the SARC-F were forwards and backwards translated by two certified Indonesian-English translators registered under legal education institutions. To ensure the translation was in the accordance with the appropriate medical content and terminologies, a geriatrician was involved in the evaluation of the final versions (FIGURE).

The Ina-FRAIL and the Ina-SARC-F were validated by comparing with reference standards. The Ina-FRAIL was compared with the Indonesian version of the Cardiovascular Health Study (CHS), whereas the Ina-SARC-F was compared with sarcopenia criteria based on the Asian Working



FIGURE. Schematic description of adaptation and validation of the FRAIL scale and the SARC-F 
Group for Sarcopenia (AWGS), the European Working Group for Sarcopenia in Older People (EWGSOP), and the International Working Group on Sarcopenia (IWGS). To fulfil assessment using the CHS, AWGS, EWGSOP, and IWGS criteria, gait speed, muscle strength, and body composition (muscle mass) were assessed. Gait speed was measured using the 6-minute walking test, in which patients walk as fast and as far as possible in a 15-m walking track in 6 minutes. Muscle strength in terms of handgrip strength was measured using a handgrip dynamometer of the dominant hand; the highest measurement of three times was taken. Muscle mass was measured using a bioelectrical impedance analysis (TANITA BC-480). The Ina-FRAIL-scale and the CHS were independently assessed by different assessors, as were the Ina-SARC-F and gait speed, muscle strength, and body composition.

The FRAIL scale consists of five domains: fatigue, resistance, ambulation, illnesses, and loss of weight. In CHS, frailty is defined as the presence of $\geq 3$ of the following criteria: (1) shrinking: unintended weight loss of $\geq 5 \mathrm{~kg}$ or weight loss of $\geq 5 \%$ between the baseline and year 1 visits, (2) exhaustion: fatigue according to responses to the two questions in the Center for Epidemiologic Studies Depression Scale, (3) low physical activity: the lowest quintile in the Physical Activity Scale for Elderly, (4) slowness: the lowest quintile in the 6-minute walking test for men and women, and (5) weakness: the lowest quintile in handgrip strength based on body mass index categorisation.3 For each component in both the FRAIL scale and CHS, 1 point is assigned if the participant has condition below the criterion, and frailty is defined as a score of $\geq 3$.

The SARC-F consists of five components: strength, assistance in walking, rise from a chair, climb stairs, and falls. Each component scores from 0 to 2 points, with a total score from 0 to 10; a total score of $\geq 4$ is defined as sarcopenia. The results by SARC-F were compared with the AWGS, EWGSOP, and IWGS criteria. According to AWGS, sarcopenia is defined as decreased skeletal muscle mass (measured by bioelectrical impedance analysis) of $<7.0 \mathrm{~kg} / \mathrm{m}^{2}$ for men and $<5.7 \mathrm{~kg} / \mathrm{m}^{2}$ for women together with a decline physiological function (gait speed of $<0.8 \mathrm{~m} / \mathrm{s}$ ) and/or diminished muscle strength (handgrip strength of $<26 \mathrm{~kg}$ for men and $<18 \mathrm{~kg}$ for women). ${ }^{9}$ The EWGSOP defines sarcopenia as low skeletal muscle mass of $<7.0 \mathrm{~kg} / \mathrm{m}^{2}$ for men and $<5.5 \mathrm{~kg} / \mathrm{m}^{2}$ for women plus one of the decline physiological function (gait speed of $\leq 0.8 \mathrm{~m} / \mathrm{s}$ ) and/or decreased muscle strength (handgrip strength of $<27 \mathrm{~kg}$ for men and $<18 \mathrm{~kg}$ for women). ${ }^{10}$ The IWGS uses only two criteria of decreased skeletal muscle mass $\left(<7.0 \mathrm{~kg} / \mathrm{m}^{2}\right.$ for men and $<5.5 \mathrm{~kg} / \mathrm{m}^{2}$ for women) and slow gait speed $(<1 \mathrm{~m} / \mathrm{s})$ to indicate muscle function. ${ }^{11}$

To achieve type I error of 0.05 and $90 \%$ power as well as minimum coefficient of item-to-total correlation of 0.3 for FRAIL scale ${ }^{12}$ and 0.4 for SARC $-\mathrm{F}^{13}$ the minimum sample size was estimated to be 92 for the Ina-FRAIL scale and 50 for the Ina-SARC-F. Internal consistency was assessed using the Cronbach's alpha, and test-retest reliability (with a 4-week interval) was assessed using the Kappa co-efficient agreement. Internal validity was assessed through content and construct validity. Content validity was confirmed by a geriatrician. Construct validity (correlation between each item to total scale score) was assessed using the Spearman correlation test. An item was considered valid if itemtotal correlation was $>0.196$ for Ina-FRAIL scale and $>0.361$ for Ina-SARC-F. External validity (correlation between Ina-FRAIL scale and CHS) was assessed using the Spearman correlation test. The SARC-F was validated by comparing standard sarcopenia criteria of the AWGS, EWGSOP, and IWGS. Associations between outcomes of Ina-SARC-F and those of AWGS, EWGSOP, and IWGS were assessed using the Fisher exact test. The diagnostic performance of the Ina-FRAIL scale and the Ina-SARC-F was assessed using the receiver operating characteristic curve analysis for the area under the curve, sensitivity, specificity, positive predictive value, negative predictive value, positive likelihood ratio, and negative likelihood ratio. Analyses were performed using SPSS (Windows version 25; IBM Corp, Armonk [NY], US).

\section{RESULTS}

A total of 101 (57 men and 44 women) and 64 (23 men and 41 women) patients were included in the validation of the Ina-FRAIL scale and the Ina-SARC-F, respectively. The mean patient age was 79 years and 74 years, respectively (TABLE $\mathbf{1}$ ).

For the Ina-FRAIL scale, internal consistency 
TABLE 1

Socio-demographics of patients in validation of the Indonesian version of the FRAIL scale (Ina-FRAIL) and the SARC-F (Ina-SARC-F).

\begin{tabular}{|c|c|c|}
\hline & $\begin{array}{c}\text { Ina-FRAIL scale } \\
(\mathrm{n}=101)^{\star}\end{array}$ & $\begin{array}{c}\text { Ina-SARC-F } \\
(\mathrm{n}=64)^{*}\end{array}$ \\
\hline \multicolumn{3}{|l|}{ Sex } \\
\hline Men & $57(56.4)$ & $23(35.9)$ \\
\hline Women & $44(43.6)$ & $41(64.1)$ \\
\hline \multicolumn{3}{|l|}{ Age, y } \\
\hline $60-69$ & $29(28.7)$ & $22(34.4)$ \\
\hline $70-79$ & $56(55.4)$ & $28(43.8)$ \\
\hline$\geq 80$ & $16(15.8)$ & $14(21.9)$ \\
\hline \multicolumn{3}{|l|}{ Education } \\
\hline Primary school & $15(14.8)$ & $20(31.3)$ \\
\hline Junior high school & $5(4.9)$ & $3(4.7)$ \\
\hline High school & $53(52.4)$ & $19(29.7)$ \\
\hline Diploma & $5(4.9)$ & $10(15.6)$ \\
\hline $\begin{array}{l}\text { Bachelor degree or } \\
\text { higher }\end{array}$ & $23(22.7)$ & $12(18.8)$ \\
\hline \multicolumn{3}{|l|}{ Ethnicity } \\
\hline Sundanese & $54(53.4)$ & $44(68.8)$ \\
\hline Javanese & $21(20.7)$ & $8(12.5)$ \\
\hline Batak & $8(7.0)$ & $4(6.25)$ \\
\hline Minang & $9(8.9)$ & $8(12.5)$ \\
\hline Sulawesian & $3(2.9)$ & $0(0)$ \\
\hline Betawi & $4(3.9)$ & $0(0)$ \\
\hline Others & $2(1.9)$ & $0(0)$ \\
\hline
\end{tabular}

* Data are presented as No. (\%) of patients

coefficient was 0.530 , and test-retest reliability was 0.951 ( $p<0.001)$. The correlation coefficients between the total score and items of fatigue, resistance, ambulation, illness, and loss of weight were 0.503 , $0.813,0.679,0.561$, and 0.317, respectively (all $\mathrm{p}<0.001)$. Correlation between the Ina-FRAIL scale and the CHS was strong ( $\mathrm{rs}=0.696,95 \%$ confidence interval $[\mathrm{CI}]=0.579-0.785, \mathrm{p}<0.001)$. The number of frailty syndrome identified using the Ina-FRAIL scale (with cut-off values of $\geq 3$ and $\geq 2$ ) and the CHS (with a cut-off value of $\geq 3$ ) are shown in TABLE 2. The diagnostic performance of the Ina-FRAIL scale using cut-off values of $\geq 3$ and $\geq 2$ was compared. The cut-off value of $\geq 2$ yielded higher sensitivity $(80 \%$ vs $56.57 \%)$ and negative predictive value $(89.3 \%$ vs $81.9 \%$ ), whereas the cut-off value of $\geq 3$ yielded higher specificity $(83.10 \%$ vs $70.42 \%)$ and positive predictive value (58.6\% vs 55.3\%) [T TABLE 3]. The area under the curve was 0.709 (95\% CI=0.609-0.811).
TABLE 2

Number of patients with frailty syndrome identified by the Cardiovascular Health Study and the Indonesian version of the FRAIL scale (Ina-FRAIL) using cut-off values of 3 and 2

\begin{tabular}{cccc}
\hline Ina-FRAIL & \multicolumn{2}{c}{ No. of patients } & p Value \\
\cline { 2 - 2 } & \multicolumn{2}{c}{ Cardiovascular Health Study } & \\
\cline { 2 - 3 } & Score of $\geq 3$ & Score of $<3$ & \\
\hline Cut-off value of $\geq 3$ & & & $<0.001$ \\
$\geq 3$ & 17 & 12 & \\
$<3$ & 13 & 59 & \\
Cut-off value of $\geq 2$ & & & \\
$\geq 2$ & 24 & 21 & \\
$<2$ & 6 & 50 & \\
\hline
\end{tabular}

For the Ina-SARC-F, sarcopenia was found in four of 64 patients based on the AWGS and EWGSOP criteria. Internal consistency of the Ina-SARC-F was 0.851 , and test-retest reliability was $1.00(\mathrm{p}<0.001)$. The correlation coefficients between the total score and items of strength, ambulation, rising, climbing, and falls were 0.646, 0.775, 0.653, 0.685 , and 0.580, respectively (all $\mathrm{r}>0.361$ and $\mathrm{p}<0.001)$. The Ina-SARC-F was associated with the AWGS and EWGSOP criteria ( $p<0.03$, TABLE 4$)$. According to reference standards, a cut-off value of $\geq 3$ in the Ina-SARC-F yielded an optimal combination of sensitivity and specificity for screening sarcopenia. The area under the curve was $0.85(95 \% \mathrm{CI}=0.73$ 0.92, TABLE 5).

\section{DISCUSSION}

In adaptation of the Ina-FRAIL scale, the imperial units (yards) were converted to the metric units (metres). There was no change in other questions after translation. Internal consistency of the Ina-FRAIL is comparable to that of the Chinese and Brazilian versions (0.485 and 0.447 , respectively). However, the Ina-FRAIL has a very good testretest reliability, compared with the Chinese and Brazilian versions. The Ina-FRAIL scale had a strong correlation (external validity) with the Indonesian version of CHS. ${ }^{14}$ This finding is also reported in the Brazilian FRAIL validation and adaptation study that also used the CHS as the reference standard. ${ }^{15}$ The diagnostic performance of the Ina-FRAIL scale is slightly higher than that of the Brazilian FRAIL scale but lower than that of the Chinese FRAIL scale. ${ }^{12,15}$ The Ina-FRAIL has better diagnostic performance 
TABLE 3

Diagnostic performance of the Indonesian version of the FRAIL scale (Ina-FRAIL) using cut-off values of 3 and 2

\begin{tabular}{lcccccc}
\hline Ina-FRAIL & $\begin{array}{c}\text { Sensitivity } \\
(95 \% \mathrm{Cl})\end{array}$ & $\begin{array}{c}\text { Specificity } \\
(95 \% \mathrm{Cl})\end{array}$ & $\begin{array}{c}\text { Positive } \\
\text { predictive value } \\
(95 \% \mathrm{Cl})\end{array}$ & $\begin{array}{c}\text { Negative } \\
\text { predictive value } \\
(95 \% \mathrm{Cl})\end{array}$ & $\begin{array}{c}\text { Positive } \\
\text { likelihood ratio } \\
(95 \% \mathrm{Cl})\end{array}$ & $\begin{array}{c}\text { Negative } \\
\text { likelihood ratio } \\
(95 \% \mathrm{Cl})\end{array}$ \\
\hline Cut-off value of $\geq 2$ & $80.00(61.4-92.3)$ & $70.42(58.4-80.7)$ & $53.3(43.4-63.1)$ & $89.3(80.8-94.5)$ & $2.70(1.8-4.0)$ & $0.28(0.1-0.6)$ \\
Cut-off value of $\geq 3$ & $56.57(37.4-74.5)$ & $83.10(72.3-91.0)$ & $58.6(43.7-72.1)$ & $81.9(74.8-87.4)$ & $3.35(1.8-6.1)$ & $0.52(0.3-0.8)$ \\
\hline
\end{tabular}

TABLE 4

Number of patients with sarcopenia identified by the Asian Working Group for Sarcopenia (AWGS), the European Working Group for Sarcopenia in Older People (EWGSOP), and the International Working Group on Sarcopenia (IWGS) criteria using a cut-off value of 4 from the Indonesian version of the SARC-F (Ina-SARC-F)

\begin{tabular}{|c|c|c|c|c|c|c|c|c|c|}
\hline \multirow{2}{*}{$\begin{array}{l}\text { Ina- } \\
\text { SARC-F }\end{array}$} & \multicolumn{3}{|c|}{ AWGS } & \multicolumn{3}{|c|}{ EWGSOP } & \multicolumn{3}{|c|}{ IWGS } \\
\hline & Sarcopenia* & $\begin{array}{c}\text { No } \\
\text { sarcopenia* }\end{array}$ & $\mathrm{p}$ Value & Sarcopenia* & $\begin{array}{c}\text { No } \\
\text { sarcopenia* }\end{array}$ & $\mathrm{p}$ Value & Sarcopenia* & $\begin{array}{c}\text { No } \\
\text { sarcopenia* }\end{array}$ & $p$ Value \\
\hline$\geq 4$ & $3(4.7)$ & $11(17.2)$ & 0.03 & $3(4.7)$ & $11(17.2)$ & 0.03 & $3(4.7)$ & $11(17.2)$ & 0.06 \\
\hline$<4$ & $1(1.6)$ & 49 (76.6) & & $1(1.6)$ & 49 (76.6) & & $2(3.1)$ & $48(75.0)$ & \\
\hline
\end{tabular}

${ }^{*}$ Data are presented as No. (\%) of patients

TABLE 5

Diagnostic performance of the Indonesian version of the SARC-F (Ina-SARC-F) using cut-off values of $\mathbf{3}$ and 4

\begin{tabular}{|c|c|c|c|c|c|c|c|}
\hline $\begin{array}{l}\text { Area under the } \\
\text { curve of the } \\
\text { Ina-SARC-F }\end{array}$ & $\begin{array}{l}\text { Ina- } \\
\text { SARC-F } \\
\text { cut-off } \\
\text { value }\end{array}$ & $\begin{array}{l}\text { Sensitivity } \\
(95 \% \mathrm{Cl})\end{array}$ & $\begin{array}{l}\text { Specificity (95\% } \\
\text { Cl) }\end{array}$ & $\begin{array}{c}\text { Positive } \\
\text { predictive value } \\
(95 \% \mathrm{Cl})\end{array}$ & $\begin{array}{c}\text { Negative } \\
\text { predictive value } \\
(95 \% \mathrm{Cl})\end{array}$ & $\begin{array}{c}\text { Positive } \\
\text { likelihood } \\
\text { ratio }(95 \% \mathrm{Cl})\end{array}$ & $\begin{array}{c}\text { Negative } \\
\text { likelihood ratio } \\
(95 \% \mathrm{Cl})\end{array}$ \\
\hline \multicolumn{8}{|l|}{$\begin{array}{l}\text { Asian Working } \\
\text { Group for } \\
\text { Sarcopenia }\end{array}$} \\
\hline \multirow{2}{*}{$\begin{array}{l}0.85(0.73-0.92) \\
p<0.001\end{array}$} & $\geq 3$ & $100(39.8-100)$ & $61.67(48.2-73.9)$ & $22.5(17.4-28.5)$ & 100.0 & $2.61(1.9-3.6)$ & 0.0 \\
\hline & $\geq 4$ & 75 (19.4-99.4) & 81.67 (69.6-90.5) & $31.2(17.3-49.7)$ & $96.7(84.3-99.4)$ & $4.09(1.9-8.9)$ & $0.31(0.06-1.7)$ \\
\hline \multicolumn{8}{|l|}{$\begin{array}{l}\text { European } \\
\text { Working Group } \\
\text { for Sarcopenia in } \\
\text { Older People }\end{array}$} \\
\hline \multirow{2}{*}{$\begin{array}{l}0.85(0.73-0.92) \\
p<0.001]\end{array}$} & $\geq 3$ & $100(39.8-100)$ & $61.67(48.2-73.9)$ & $22.5(17.4-28.5)$ & 100.0 & 2.61 (1.9-3.6) & 0.0 \\
\hline & $\geq 4$ & 75 (19.4-99.4) & $81.67(69.6-90.5)$ & $31.2(17.3-49.7)$ & 96.7 (84.3-99.4) & 4.09 (1.9-8.9) & $0.31(0.06-1.7)$ \\
\hline \multicolumn{8}{|l|}{$\begin{array}{l}\text { International } \\
\text { Working Group } \\
\text { on Sarcopenia }\end{array}$} \\
\hline \multirow{2}{*}{$\begin{array}{l}0.82(0.70-0.90) \\
p<0.001\end{array}$} & $\geq 3$ & $100(47.8-100)$ & $62.71(49.1-75.0)$ & $23.0(17.6-29.3)$ & 100.0 & $2.68(1.9-3.7)$ & 0.0 \\
\hline & $\geq 4$ & $60(14.7-94.7)$ & 81.36 (69.1-90.3) & $26.3(12.8-46.6)$ & $94.8(86.1-98.2)$ & $4.09(1.9-8.9)$ & $0.49(0.2-1.4)$ \\
\hline
\end{tabular}

than the Brazilian version when using the cut-off value of $\geq 3$ (sensitivity: $56 \%$ vs $28 \%$, specificity: $83 \%$ vs $90 \%$ ) or the cut-off value of $\geq 2$ (sensitivity: $80 \%$ vs $54 \%$, specificity: $70.42 \%$ vs $73 \%) .{ }^{15}$ Sensitivity of the Ina-FRAIL scale is comparable to that of the Chinese FRAIL scale when using the cut-off value of $\geq 2$ ( $80 \%$ vs $86.96 \%)$ or the cut-off value of $\geq 3(56.57 \%$ vs $52.17 \%){ }^{12}$ Using the Frailty Index as reference criteria, the Korean version of FRAIL scale has high sensitivity (90\%) but markedly low specificity (30\%) to detect frailty syndrome. ${ }^{16}$

The FRAIL scale has been validated into various languages through evaluating the clinical outcomes, health functioning, hospitalisation, comorbidities, and mortality. ${ }^{17,18}$ We conducted the validation study 
by comparing the Ina-FRAIL scale with the CHS, but we did not evaluate clinical outcomes, which require a prospective study for a better external validity assessment.

In adaptation of the Ina-SARC-F, in item 1 (ability to lift and carry 10 pounds), the imperial units (pounds) were converted to metric units (kilograms). In item 4 (ability to climb 10 stairs), patients living in the rural areas who seldom go to a building with multiple floors may interpret differently. Therefore, the assessor must understand the idea to elicit whether the patient has difficulty in reaching a higher level of ground. Further adaptation of the Ina-SARC-F for the rural population is needed. We did not find any problem in adaptation of the remaining items.

The Ina-SARC-F yielded similar results with other versions. ${ }^{10,13,19,20}$ Screening for sarcopenia using the SARC-F is important in preventing falls, frailty, functional decline, and hospitalisation, and also may decrease mortality in older adults through early detection. Similar to Ina-SARC-F, the Mexican version of the SARC-F is also validated by comparing with the AWGS, EWGSOP, and IWGS criteria. Reliability of the Ina-SARC-F is comparable to that of the Mexican version ${ }^{13}$ but is higher than the Japanese SARC-F. ${ }^{21}$

For the Ina-SARC-F, the cut-off value of $\geq 3$ yielded the best diagnostic performance, with sensitivity of $100 \%$ and specificity of $62.7 \%$. If the cut-off value of $\geq 4$ was used, the specificity increased to $81.4 \%$ but the sensitivity decreased to $75 \%$. The Ina-SARC-F yields higher sensitivity $(100 \%$ and $75 \%$ for cut-off values of $\geq 3$ and $\geq 4$, respectively), compared with the Mexican, Korean, and Japanese versions that have sensitivity ranging from $14 \%$ to $35 \% .{ }^{13,20,21}$ We will still use the same cut-off value $(\geq 4)$ of the original English version, because it has been validated. To validate the Ina-SARC-F in terms of clinical outcomes, further longitudinal study is needed to observe adverse outcomes as sarcopenia primary endpoint.

According to our results, the cut-off value of $\geq 2$ for the Ina-FRAIL scale and the cut-off value of $\geq 3$ for the Ina-SARC-F yielded the optimal sensitivity and modest specificity. The Ina-FRAIL scale and Ina-SARC-F are suitable screening tools for frailty syndrome and sarcopenia, respectively. The lower cut-off values yielded more sensitivity but less specificity, whereas the higher cut-off values yielded more specificity but less sensitivity. Therefore, both can be applied in various clinical settings. In primary healthcare settings with limited resources, the lower cut-off values may be more appropriate for screening so that more older people with frailty can be screened for more thorough examinations in the referral hospitals. The original cut-off values for the FRAIL scale $(\geq 3)$ and the SARC-F $(\geq 4)$ still can be used as a reference in referral hospitals or other healthcare facilities capable of performing more comprehensive examinations and can be used to confirm the frailty status and sarcopenia diagnosis.

One limitation of our study was the small sample size. However, our sample is representative of Indonesia, as it includes patients from various backgrounds, ethnicities, and education levels. In addition, our study did not validate the instruments with clinical outcomes such as morbidity, mortality, hospitalisation, and fall risk. Further longitudinal studies to observe such adverse outcomes are needed.

\section{CONCLUSIONS}

The Ina-FRAIL scale and the SARC-F are reliable valid screening tools to detect frailty syndrome and sarcopenia, respectively.

\section{FUNDING}

This research did not receive any funding from agencies in the public, commercial, or not-for-profit sectors.

\section{DECLARATION}

The authors have no conflicts of interest to disclose.

\section{REFERENCES}

1. Adioetomo SM, Mujahid G. Indonesia on the threshold of population ageing. Jakarta: 2014.

2. Chen X, Mao G, Leng SX. Frailty syndrome: an overview. Clin Interv Aging 2014;9:433-41. Crossref

3. Fried LP, Tangen CM, Walston J, Newman AB, Hirsch C, Gottdiener J, et al. Frailty in older adults: evidence for a phenotype. J Gerontol A Biol Sci Med Sci 2001;56:M146-56. Crossref

4. Morley JE, Vellas B, van Kan GA, Anker SD, Bauer JM, Bernabei R, et al. Frailty consensus: a call to action. J Am Med Dir Assoc 2013;14:392-7. Crossref 
5. Morley JE. Frailty, falls, and fractures. J Am Med Dir Assoc 2013;14:149-51. Crossref

6. Morley JE, Malmstrom TK, Miller DK. A simple frailty questionnaire (FRAIL) predicts outcomes in middle aged African Americans. J Nutr Health Aging 2012;16:601-8. Crossref

7. Woo J, Yu R, Wong M, Yeung F, Wong M, Lum C. Frailty screening in the community using the FRAIL scale. J Am Med Dir Assoc 2015;16:412-9. Crossref

8. Morley JE, Cao L. Rapid screening for sarcopenia. J Cachexia Sarcopenia Muscle 2015;6:312-4. Crossref

9. Chen LK, Liu LK, Woo J, Assantachai P, Auyeung TW, Bahyah $\mathrm{KS}$, et al. Sarcopenia in Asia: consensus report of the Asian Working Group for Sarcopenia. J Am Med Dir Assoc 2014;15:95101. Crossref

10. Cruz-Jentoft AJ, Baeyens JP, Bauer JM, Boirie Y, Cederholm T, Landi F, et al. Sarcopenia: European consensus on definition and diagnosis: report of the European Working Group on Sarcopenia in Older People. Age Ageing 2010;39:412-23. Crossref

11. Fielding RA, Vellas B, Evans WJ, Bhasin S, Morley JE, Newman AB, et al. Sarcopenia: an undiagnosed condition in older adults. Current consensus definition: prevalence, etiology, and consequences. International working group on sarcopenia. J Am Med Dir Assoc 2011;12:249-56. Crossref

12. Dong L, Qiao X, Tian X, Liu N, Jin Y, Si H, et al. Cross-cultural adaptation and validation of the FRAIL Scale in Chinese community-dwelling older adults. J Am Med Dir Assoc 2018;19:12-7. Crossref

13. Parra-Rodriguez L, Szlejf C, Garcia-Gonzalez AI, Malmstrom TK, Cruz-Arenas E, Rosas-Carrasco O. Cross-cultural adaptation and validation of the Spanish-language version of the SARC-F to assess sarcopenia in Mexican community-dwelling older adults. J Am Med Dir Assoc 2016;17:1142-6. Crossref

14. Seto E, Setiati S, Laksmi PW, Tamin TZ. Diagnostic test of a scoring system for frailty syndrome in the elderly according to Cardiovascular Health Study, Study of Osteoporotic Fracture and Comprehensive Geriatric Assessment based Frailty Index compared with Frailty Index 40 Items. Acta Med Indones 2015;47:183-7.

15. Aprahamian I, Cezar NOC, Izbicki R, Lin SM, Paulo DLV, Fattori A, et al. Screening for frailty with the FRAIL scale: a comparison with the phenotype criteria. J Am Med Dir Assoc 2017;18:592-6. Crossref

16. Jung HW, Yoo HJ, Park SY, Kim SW, Choi JY, Yoon SJ, et al. The Korean version of the FRAIL scale: clinical feasibility and validity of assessing the frailty status of Korean elderly. Korean J Intern Med 2016;31:594-600. Crossref

17. Lopez D, Flicker L, Dobson A. Validation of the frail scale in a cohort of older Australian women. J Am Geriatr Soc 2012;60:1713. Crossref

18. Díaz de León González E, Gutiérrez Hermosillo H, Martinez Beltran JA, Chavez JH, Palacios Corona R, Salinas Garza DP, et al. Validation of the FRAIL scale in Mexican elderly: results from the Mexican Health and Aging Study. Aging Clin Exp Res 2016;28:901-8. Crossref

19. Malmstrom TK, Miller DK, Simonsick EM, Ferrucci L, Morley JE. SARC-F: a symptom score to predict persons with sarcopenia at risk for poor functional outcomes. J Cachexia Sarcopenia Muscle 2016;7:28-36. Crossref

20. Kim S, Kim M, Won CW. Validation of the Korean version of the SARC-F questionnaire to assess sarcopenia: Korean Frailty and Aging Cohort Study. J Am Med Dir Assoc 2018;19:40-45. e1. Crossref

21. Ida S, Murata K, Nakadachi D, Ishihara Y, Imataka K, Uchida A, et al. Development of a Japanese version of the SARC-F for diabetic patients: an examination of reliability and validity. Aging Clin Exp Res 2017;29:935-42. Crossref 
Appendix 1. English and Indonesian versions of the FRAIL scale

\begin{tabular}{|c|c|}
\hline English version & Indonesian version \\
\hline $\begin{array}{l}\text { Fatigue } \\
\text { How much of the time during the past } 4 \text { weeks did you } \\
\text { feel tired? } \\
1=\text { All of the time, } 2=\text { Most of the time, } 3 \text { = Some of } \\
\text { the time, } 4=\text { Little of the time, } 5=\text { None of the time; } \\
\text { responses of } 1 \text { or } 2 \text { are score as } 1 \text { and all others as } 0\end{array}$ & $\begin{array}{l}\text { A = Aktifitas (fatigue) } \\
\text { Seberapa sering dalam } 4 \text { minggu ada merasa kelelahan? } \\
1=\text { Sepanjang waktu, } 2=\text { Sebagian besar waktu, } 3= \\
\text { Kadang }- \text { kadang, } 4=\text { Jarang; Bila jawab } 1 \text { atau } 2 \text { skor }=1 \\
\text { dan selain itu skor }=0\end{array}$ \\
\hline $\begin{array}{l}\text { Resistance } \\
\text { By yourself and not using aids, do you have any difficulty } \\
\text { walking up steps without resting? } \\
1=\text { Yes, } 0=\text { No }\end{array}$ & $\begin{array}{l}\text { R = Resistensi (resistance) } \\
\text { Dengan diri sendiri atau tanpa bantuan alat, apakah } \\
\text { anda mengalami kesulitan untuk naik } 10 \text { anak tanggadan } \\
\text { tanpa istirahat diantaranya? } \\
\text { Skor } 1=Y a, 0=\text { Tidak }\end{array}$ \\
\hline $\begin{array}{l}\text { Ambulation } \\
\text { By yourself and not using aids, do you have any difficulty } \\
\text { walking several hundred yards? } \\
1=\text { Yes, } 0=\text { No }\end{array}$ & $\begin{array}{l}\text { Usaha berjalan (ambulatory) } \\
\text { Dengan diri sendiri dan tanpa bantuan, apakah anda } \\
\text { mengalami kesulitan berjalan kira - kira sejauh } 100 \\
\text { sampai } 200 \text { meter? } \\
\text { Skor } 1=\text { Ya, } 0=\text { Tidak }\end{array}$ \\
\hline $\begin{array}{l}\text { Illness } \\
\text { For } 11 \text { illness participans are asked, Did a doctor ever tell } \\
\text { you that you have [illness]? } \\
1=\text { Yes, } 0=\text { No. The total illnesses (0-11) are recoded as } \\
0-4 \text { and 5-11. } \\
\text { The illnesses include hypertension, diabetes, cancer, } \\
\text { (other than a minor skin cancer), chronic lung disease, } \\
\text { heart attack, congestive heart failure, angina, asthma, } \\
\text { arthritis, and kidney disease. }\end{array}$ & $\begin{array}{l}\text { P = Penyakit lebih dari (illnesses) } \\
\text { Partisipan ditanya, apakah dokter pernah mengatakan } \\
\text { kepada anda tentang penyakit anda (11 penyakit utama: } \\
\text { hipertensi, diabets, kanker (selain kanker kulit kecil), } \\
\text { penyakit paru kronis, serangan jantung, gagal jantung } \\
\text { kongestif, nyeri dada, asma, nyeri sendi, stroke dan } \\
\text { penyakit ginjal)? } \\
\text { Bila jawaban jumlah total penyakit skor yang tercatat } 0-4 \\
\text { penyakit = } 0 \text { dan } 5-11 \text { penyakit = } 1\end{array}$ \\
\hline $\begin{array}{l}\text { Loss of weight } \\
\text { How much do you weigh with your clothes on but } \\
\text { without shoes? (current weight) one year ago in (month, } \\
\text { year); how much did you weigh without your shoues } \\
\text { with your clothes on? (weight } 1 \text { year ago) percent weight } \\
\text { change is computed as [(weight } 1 \text { year ago - current } \\
\text { weight)/weight } 1 \text { year ago] x } 100 \% \text {; percent change } \\
>5 \text { (representing } 5 \% \text { loss of weight) is scored as } 1 \text { and } \\
<5 \text { as } 0 \text {. }\end{array}$ & $\begin{array}{l}\text { H = Hilangnya berat badan (loss of weight) } \\
\text { Berapa berat badan saudara dengan mengenakan baju } \\
\text { tanpa alas kaki saat ini? Satu tahun yang lalu, berapa } \\
\text { berat badan anda dengan mengenakan baju tanpa } \\
\text { alas kaki? Keterangan perhitungan berat badan dalam } \\
\text { persen : [(berat badan } 1 \text { tahun yang lalu - berat badan } \\
\text { sekarang)/Berat badan satu tahun lalu)]x } 100 \% \text {; bila hasil } \\
>5 \% \text { (mewakili kehilangan berat badan } 5 \% \text { ) diberi skor } 1 \\
\text { dan }<5 \% \text { skor }=0\end{array}$ \\
\hline
\end{tabular}

\section{Appendix 2. English and Indonesian versions of the SARC-F}

\begin{tabular}{|c|c|}
\hline English version & Indonesian version \\
\hline $\begin{array}{l}\text { S = Strength: How much difficulty do you have in lifting } \\
\text { and carrying } 10 \text { pounds? } \\
0=\text { None, } 1=\text { Some, } 2=\text { A lot or unable }\end{array}$ & $\begin{array}{l}\text { S = Kekuatan: Seberapa sulit Anda dalam mengangkat } \\
\text { dan membawa beban seberat } 5 \mathrm{~kg} \text { ? } \\
0=\text { Tidak ada kesulitan, } 1=\text { Cukup sulit, } 2 \text { = Sangat sulit } \\
\text { atau tidak mampu }\end{array}$ \\
\hline $\begin{array}{l}\text { A = Assistance to walk: How much difficulty do you } \\
\text { have walking across a room? } \\
0=\text { None, } 1 \text { = Some, } 2 \text { = A lot, use aids, or unable } \\
\mathbf{R}=\text { Raise up from a chair: How much difficulty do you } \\
\text { have transferring from a chair or a bed? } \\
0=\text { None, } 1 \text { = Some, } 2 \text { = A lot or unable }\end{array}$ & $\begin{array}{l}\text { A = Bantuan untuk berjalan: Seberapa sulit Anda } \\
\text { berjalan melintasi ruangan? } \\
0=\text { Tidak ada kesulitan, } 1 \text { = Cukup sulit, } 2 \text { = Sangat sulit, } \\
\text { perlu bantuan atau tidak mampu } \\
\mathbf{R}=\text { Bangkit dari kursi: Seberapa sulit Anda bangkit } \\
\text { dan berpindah dari kursi/tempat tidur? } \\
0=\text { Tidak ada kesulitan, } 1 \text { = Cukup sulit, } 2 \text { = Sangat sulit } \\
\text { atau tidak mampu jika tanpa bantuan }\end{array}$ \\
\hline $\begin{array}{l}\mathbf{C}=\text { Climb the stairs: How much difficulty do you have } \\
\text { climbing a flight of ten stairs? } \\
0=\text { None, } 1=\text { Some, } 2=\text { A lot or unable } \\
\mathbf{F}=\text { Falling: How many times have you fallen in the last } \\
\text { year? } \\
0=\text { None, } 1=1-3 \text { falls, } 2=4 \text { or more falls }\end{array}$ & $\begin{array}{l}\text { C = Menaiki tangga: Seberapa sulit Anda menaiki } \\
\text { sepuluh anak tangga? } \\
0=\text { Tidak ada kesulitan, } 1=\text { Cukup sulit, } 2=\text { Sangat sulit } \\
\text { atau tidak mampu } \\
\text { F = Jatuh: Berapa kali Anda jatuh dalam satu tahun } \\
\text { terakhir? } \\
0=\text { Tidak pernah, } 1=1-3 \text { kali, } 2=4 \text { atau lebih }\end{array}$ \\
\hline
\end{tabular}

